\title{
ABC Transporters: Maintenance of the Cancer Stem Cell Phenotype
}

\author{
Wei Zhang and Li-Wu Fu*
}

State Key Laboratory of Oncology in Southern China, Cancer Center, Sun Yat-Sen University, Guangzhou, 510060, China

\begin{abstract}
The poor therapeutic response to anti-cancer treatment and inferior prognosis of carcinoma primarily result from cancer stem cells (CSCs), which initiate and maintain tumors. Recent studies have demonstrated that the molecular phenotype of CSCs mainly consists of multidrug resistance (MDR), self-renewal, multi-lineage differentiation potential (pluripotency) and tumorigenicity. Intriguingly, ATP-binding cassette (ABC) membrane transporters are highly expressed in CSCs compared to non-CSCs, and recent evidence has highlighted a link between ABC transporters and the CSC phenotype. Understanding the relationship between CSCs and ABC transporters is important as this could lead to the development of more efficacious treatment regimens. Thus, in this article, we will mainly review the relationships between $A B C$ transporters and the phenotype of CSCs.
\end{abstract}

Keywords: ABC transporters, cancer stem-like cells (CSCs), multidrug resistance (MDR), self-renewal, pluripotency, side population (SP), tumorigenicity.

\section{INTRODUCTION}

In recent years, although great progress has been made in the treatment of against cancer, the refractory status of cancer, including chemo-resistance, recurrence and metastasis, remains a major challenge. The understanding of the causes responsible for the failure of anticancer agents, recurrence and metastasis of tumors is of great importance. Emerging studies have shown that cancer stem-like cells (CSCs) play a key role in these processes [1-6]. Malignant stem-like cells have been identified in various solid tumor and leukemia. Similar to normal stem cells, CSCs are able to self-renew, differentiate, and proliferate extensively $[7,8]$. The cancer mass that originates from rare stemlike cells can transfer the disease to immunodeficient mice, suggesting that these cancer stem-like cells (CSCs) are responsible for relapse following conventional or targeted cancer therapy and that eradication of CSCs may be necessary to cure the disease permanently. However, current therapeutic strategies may not effectively ablate the CSCs, leaving the potential for disease progression or relapse.

The ATP binding cassette $(A B C)$ transporters are ubiquitous membrane proteins, consisting of both transmembrane domains (TMDs) and distinctive nucleotide-binding domains (NBDs), which generate energy from ATP hydrolysis to actively transport a variety of compounds across the membrane [9-11]. Based on sequence homology and domain

*Address correspondence to this author at the Cancer Center, Sun Yat-Sen University, Guangzhou 510060, Guangdong Province, China; Tel: +86-20-873431-63; Fax: +86-20- 873-431-70; E-mail: Fulw@mail.sysu.edu.cn organization of the TMDs, the ABC family of transporters can be divided into seven distinct subfamilies (ABCA-ABCG), which are further divided into sub-subfamilies (except the ABCE/OABP family) $[12,13]$ (Table 1).

One of the important physiological roles of most of these proteins is to pump out diverse endogenous substrates including sugars, amino acids, peptides, proteins, and other hydrophobic compounds using the energy of ATP hydrolysis [10,11]. In addition, these transporters catalyze the efflux of numerous xenobiotics, including antineoplastic drugs, thereby protecting normal tissues from cytotoxic effects [14, 15].

The overexpression of $\mathrm{ABC}$ drug transporters confers cross-resistance to multiple drugs belonging to different chemical classes via active efflux and thus, reducing the intracellular levels below that required to produce a therapeutic effect, resulting in MDR [16]. About 13 14 out of 49 members of the ABC protein family may produce MDR in cancer cells. The most important members in mediating MDR are $A B C B 1 / P$ gp, ABCG2/BCRP and ABCC1/MRP1 [11, 15, 17].

Currently, in addition to MDR, a large body of evidence indicates that there are some links between ABC transporters and the CSC phenotype [18, 19]. The elucidation of the relationship between $A B C$ transporters and CSCs may provide a basis for improving therapeutic interventions against malignant cancer. Therefore, in this paper, we review the relationships between $A B C$ transporters and the CSC properties including MDR, self-renewal, pluripotency and tumorigenicity. 
Table 1: Classification of the Human ABC Transporter Family and Members that Determine MDR

\begin{tabular}{|c|c|c|c|c|}
\hline \multirow{2}{*}{ Subfamily } & \multirow{2}{*}{ Alternative name } & \multirow{2}{*}{ Number of proteins } & \multicolumn{2}{|c|}{ Proteins that confer drug resistance } \\
\hline & & & Name & Number \\
\hline $\mathrm{ABCA}$ & $\mathrm{ABC} 1$ & 12 & $\mathrm{ABCA} 2$ & 1 \\
\hline \multirow{3}{*}{$\mathrm{ABCB}$} & \multirow{3}{*}{ MDR } & \multirow{3}{*}{11} & ABCB1(P-gp) & \multirow{3}{*}{3} \\
\hline & & & ABCB4(MDR3) & \\
\hline & & & ABCB11(BSEP,SPGP) & \\
\hline \multirow{4}{*}{$\mathrm{ABCC}$} & \multirow{4}{*}{ MRP } & \multirow{4}{*}{13} & ABCC2-6(MPR2-6) & \multirow{4}{*}{9} \\
\hline & & & ABCC10(MPR7) & \\
\hline & & & ABCC11(MRP8) & \\
\hline & & & ABCC12(MRP9) & \\
\hline $\mathrm{ABCF}$ & GCN20 & 3 & & \\
\hline$A B C G$ & White & 5 & ABCG2(BCRP) & 1 \\
\hline Total & & 49 & & 14 \\
\hline
\end{tabular}

\section{ABC TRANSPORTERS AND MDR OF CSCs}

The failure of cancer chemotherapy can occur through acquired-resistance or intrinsic resistance to antineoplastic drugs [20, 21]. The nature of clinical drug resistance is multifactorial, involving alterations in drug targets, inactivation/detoxification of the drug, decreased drug uptake, increased drug efflux, and the dysregulation of apoptotic pathways [22]. The reduction of intracellular drug levels can be mediated by an increased expression of specific ATP binding cassette $(A B C)$ transporters, which are responsible for multidrug resistance (MDR) [23]. The most extensively characterized $A B C$ transporters that mediate MDR are ABCB1 (also known as MDR1 or P-glycoprotein), ABCC1 (also known as MRP1) and ABCG2 (also known as BCRP or MXR) [24].

\subsection{ABCB1 and MDR of CSCs}

ABCB1 (P-gp), a 170-kDa transmembrane glycoprotein from the superfamily of ATP binding cassette transporters, serves as an ATP-dependent efflux pump for a variety of chemicals, including many antineoplastic agents such as taxanes, anthracyclines and vinca alkaloids [25]. Furthermore, numerous studies indicate that the overexpression of $A B C B 1$ is associated with multidrug resistance (MDR) [15, 26, 27].

Cancer stem-like cells are defined as "a small subset of cancer cells within a cancer that constitute a reservoir of self-sustaining cells with the exclusive ability to self-renew and to cause the heterogeneous lineages of cancer cells that comprise the tumor" [28]. Currently,, there is considerable evidence indicating that $A B C B 1$ transporters are overexpressed in various types of CSCs [29-36]. Interestingly, these cancer stem-like cells are resistant to a variety of conventional therapies [37]. Therefore, ABCB1 may be responsible for the MDR of CSCs, mainly through the efflux of antineoplastic drugs.

There are several mechanisms that may mediate the ABCB1-induced MDR of CSCs: (1) overexpression of $A B C B 1 ;$ (2) functional abnormality in $A B C B 1$ [38, 39]; (3) the presence of subcellular P-gp [40]; (4) inhibition of cisplatin-induced caspase-3 activation [41]; (5) modulation of intracellular calcium homeostasis [4246];

\subsection{ABCC1 and MDR of CSCs}

Apart from P-gp, multidrug-associated protein 1 (MRP1 or ABCC1) also plays a role in the development of drug resistance in the majority human cancers, including those of the lung, breast and prostate, as well as childhood neuroblastomas [47]. The ABCC1 transporter was the first member of the MRP family reported to be linked with MDR [48]. It catlyzes the efflux of antineoplastic drugs such as anthracyclines and mitoxantrone, as well as drugs conjugated to glutathione- (GSH), sulfate- or glucuronate [49]. 
Numerous studies have shown MRP1 is overexpressed in a variety of solid tumors and MRP1 mediates drug resistance in several types of cancers [47]. A study by Marques et al. found that Lucena cells resistant to chemotherapy (also expressing $\mathrm{CD} 34^{+} \mathrm{CD} 38^{-}$) significantly overexpressed ABCC1 genes [50]. Moreover, Vesuna et al. found the first direct evidence demonstrating that increased $A B C C 1$ transporter levels in Twist-overexpressing cells lead to the development of chemo-resistance and development of the stem cell phenotype in these cells [51]. In addition, both in vitro and in vivo studies have reported that down-regulation of MRP1 in cancer cell lines or tumor xenografts produces significant chemosensitization to clinically relevant MRP1 substrate drugs, thereby verifying its role in MDR [52-54].

\subsection{ABCG2 and MDR of CSCs}

ABCG2 (BCRP, breast cancer resistance protein, $A B C P$ or MXR) was first identified in a MCF-7/AdrVp3000 cancer cell line that neither expressed P-gp nor MRP1 but exhibited a high resistance to doxorubicin, mitoxantrone and daunorubicin [55]. The mediation of chemoresistance by ABCG2 was first reported by Zhou et al. who demonstrated that stem cells derived from ABCG2 deficient mice were more sensitive to mitoxantrone, an antioneoplastic drug that is a substrate for ABCG2 [56]. Numerous in vitro studies indicate that the overexpression of the ABCG2 transporter is correlated with MDR in various types of cancers [57]. Furthermore, a study by Bhatia et al. reported that ABCG2 is expressed in the nuclear extracts of select glioblastoma and astrocytoma cell lines as well as in a human ABCG2 tumor biopsy [58].

Overall, ABCG2 and P-gp play a critical role in chemoresistance in CSCs or SP cells, though the detailed relationship between them remains unknown. $A B C$ transporters- mediated MDR involves not only the expression level and functional activity of $A B C$ transporters, but also the subcellular location of $A B C$ transporters. Recent studies suggest that $A B C$ transporter-mediated MDR may also occur by their interaction with certain cell regulatory pathways [59], down-regulation of cell surface saccharide targets [60], interaction with intracellular calcium homeostasis and by regulating endoplasmic reticulum proteins [42, 61].

\section{ABC TRANSPORTERS AND SELF-RENEWAL CAPACITY OF CSCS}

Self-renewal is the process where a stem cell divides to generate one (asymmetric division) or two (symmetric division) daughter stem cells indistinguishable from those of the mother cells, while preserving their developmental potentials [62]. Unlike normal stem cells or embryonic stem cells, cancer stem cells have an unlimited self-renewal capability [62]. Recently, multiple lines of evidence indicate that selfrenewal is regulated by a variety of signal transduction pathways, different transcription factors, and many molecular events. These include the expression of Sox2 [63, 64], Oct-4 [65-69], Nanog [70], Myc [71], Bmi-1 [72-79] and the stem cell signaling pathways: Notch [80, 81], Wnt [82-86] and Hedgehog [87, 88]. Additionally, recent evidence indicates that transcription factors associated with self-renewal pathways modulate the expression of some $A B C$ transporters, and thus maintain the self-renewal capability of cancer stem cells [89] (Figure 1). For example, Marques et al. suggested that ABCB1 may be responsible for self-renewal capacity differences between the K562 and Lucena cell line, due to the Oct4-induced changes in P-gp expression in the Lucena cell line [50]. Also, recent in vitro experiments in esophageal and prostate cancer cell lines suggest that the $\mathrm{Hh}$ pathway increases the expression of $\mathrm{ABC}$ transporters P-gp and ABCG2 [90]. In addition, the knockdown of transcription factor Gli decreased the expression of BCRP and P-gp [90, 91]. Moreover, the translocation of Gli increases the expression of ABCB1, $A B C C 1$, and $A B C G 2$ [92]. The aforementioned studies suggest that there is an association between the aberrant self-renewal related pathways and the overexpression of $A B C$ transporter Currently, the specific relationship between $A B C$ transporters and the capacity of self-renewal in CSCs remains unknown. However, there are several postulated mechanisms by which $A B C$ transporters could produce self-renewal in CSCs. For example, it is possible that ABCG2 expression could reduce the accumulation of DNAdamaging metabolites in mouse embryonic stem cells (ESCs), which helps prevent cell differentiation but maintain self-renewal [93]. An increase in the level of ABCG2 was observed in the colony expansion of embryonic stem (ES), followed by a decrease in the level of protoporphyrin IX (PPIX) [75]. These results suggest that $A B C G 2$ plays a role in preventing porphyrin accumulation in ES cells and excessive production of ROS from heme metabolism during colony expansion [94] (Figure 2). Overall, based on the current experimental evidence, it is possible that selfrenewal-related pathways (e.g. Hegdehog) and transcription factors could modulate self-renewal process through regulating $A B C$ transporters. 


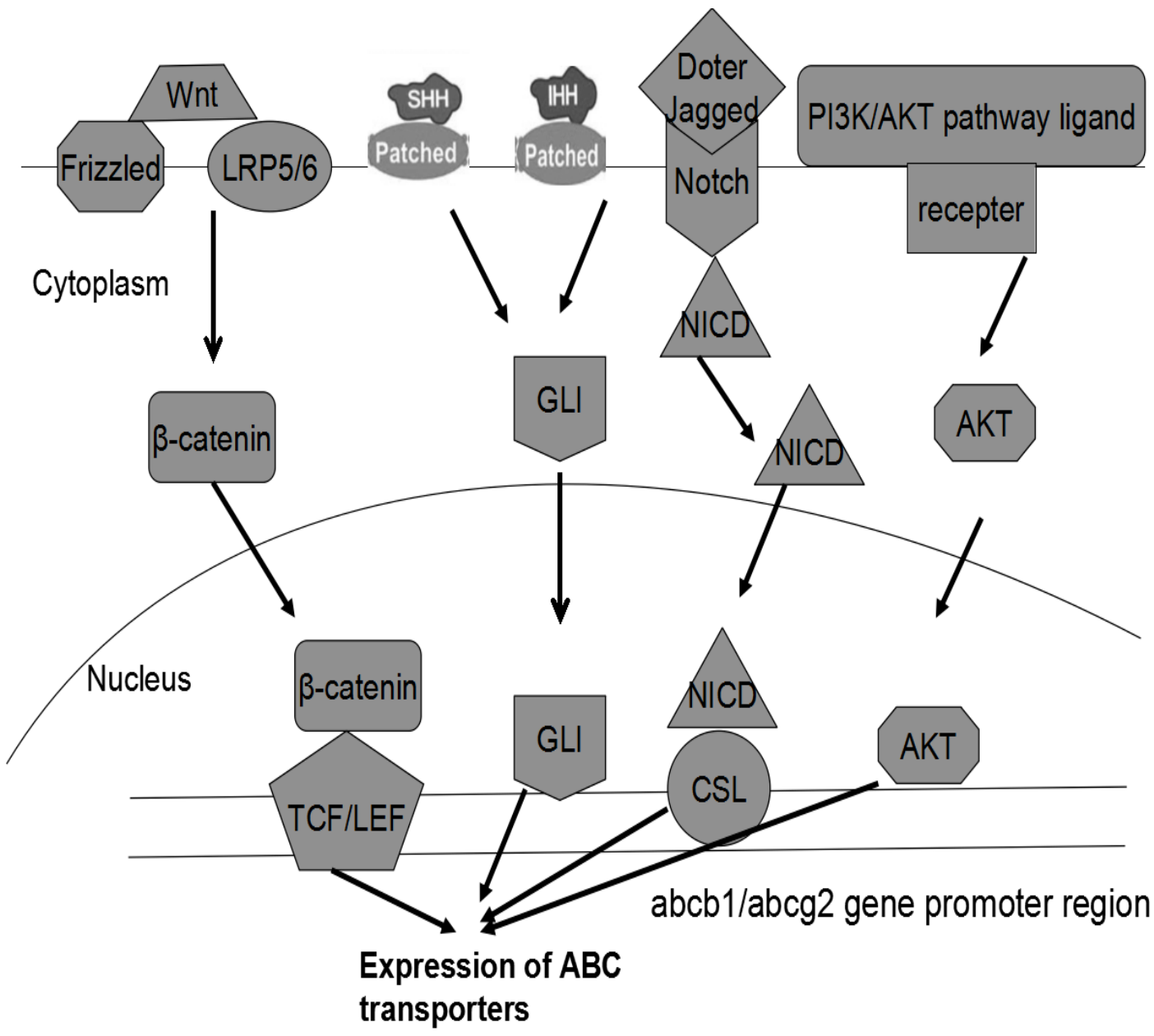

Figure 1: The effects of CSCs associated pathways on the expression of ABC transporters. ABC transporters have been shown to be regulated by the Hedgehog, Notch, and Wnt pathways. The activation of the Wnt pathway releases $\beta$-catenin from a repression complex and it translocates to the nucleus, where it interacts with the TCF/LEF consensus binding sites on the basal promoter of $\mathrm{ABC}$ transporter genes, which leads to the their expression. Also, when the ligand $\mathrm{SHH}$ or $\mathrm{IHH}$ act with Patched, the Hedgehog pathway is activated. And its effector GLI translocates to the nucleus and bonds to the promoter of ABC transporters, which result in the expression of $A B C$ transporters. In addition, when Doter and jagged bond to the Notch complex, an active component named NICD (Notch intracellular domain) is generate and it interacts with the CSL of promoter of the ABC transporters, thereby increasing their expression. The activation of the PI3K/AKT pathway also can produce the expression of $A B C$ transporters through the binding of $A K T$ with the $A B C$ transporter gene promoter.

Therefore, the relationship between self-renewal and ABC transporters may provide a novel therapeutic strategy for overcoming the maintenance and survival of cancer stem cells.

\section{ABC TRANSPORTERS AND PLURIPOTENCY OF CSCs}

Cancer stem-like cells possess the ability to generate all types of cancer cell types (pluripotency), which form the heterogeneous macroscopic tumors [95]. Recent studies have revealed that some stem cell-like markers, such as Nanog, Oct3/4, c-Myc and Sox-2, are associated with pluripotency $[68,69,96$, 97]. Similarly, multiple lines of evidence indicate that $A B C$ transporters, such as $A B C B 1$ and $A B C G 2$, are markers of cancer stem-like cells, and may be responsible for some key traits of cancer stem-like cells, such as the self-renewal and $\operatorname{MDR}[56,98]$. However, to date, little is known about the detailed interaction of $A B C$ transporters and pluripotency of cancer stem-like cells. Recent studies have indicated that $A B C$ transporters may play a specific role in the maintenance of pluripotency of some types of normal tissue stem/progenitor cells, as indicated by the fluctuation in the expression of $A B C$ transporters during differentiation and regeneration of different kinds of normal tissue stem/progenitor cells [99-101]. For example, a study by Juuti-Uusitalo $\mathrm{K}$ et al. found that the gene expression of MRP1, -3, -4, -5, and P-gp fluctuated during hESC-RPE (human stem cell-derived retinal pigment epithelial cells) maturation from undifferentiated hESC to fusiform, epithelioid, and 


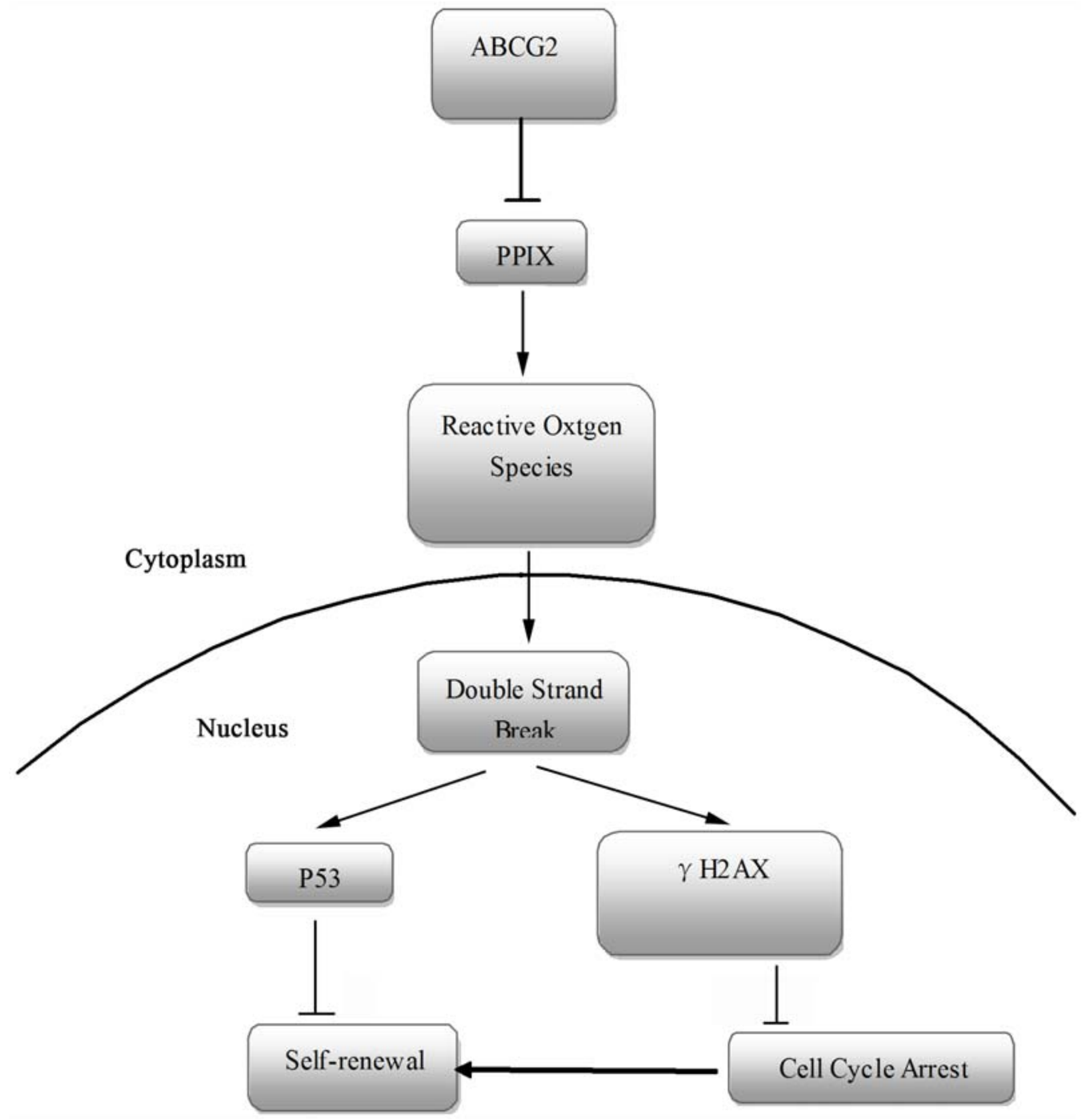

Figure 2: The possible mechanism of ABCG2 mediated self-renewal of CSCs. ABCG2 plays a role in preventing the accumulation of porphyrin and DNA damaging agents which triggers DNA damage signals such as Patm, pp53 and yH2AX.

finally to cobblestone hESC-RPE [99]. Furthermore, Islam et al. found that ABCB1 expression decreased during human fetal neural stem/progenitor cells (hNSPCs) differentiation and that ABCB1 may maintain hNSPCs in an undifferentiated state and could be a neural stem/progenitor marker [101]. More importantly, Barbet et al. reported that the expression of the 49 human ATP binding cassette (ABC) genes (except $A B C B 5, A B C C 11, A B C C 12, A B C G 5, A B C G 8)$ in pluripotent embryonic stem cells and in early- and latestage multipotent mesenchymal stem cells may play a role in maintaining human stem cell pluripotency [100]. A recent study has shown that $A B C$ transporters contribute to both local and global regulation of CAMP, a ubiquitous second messenger that affects multiple cell functions from maturation of the egg to cell division, growth, differentiation, and death [102]. However, the evidence discussed above is correlative and definitive studies are needed to 1) determine whether the expression of $A B C$ transporters is associated with the pluripotency of cancer stem cells and 2) determine the mechanism.

\section{ABC TRANSPORTERS AND TUMORIGENICITY OF CSCs}

The $A B C$ transporters appear to play an important role in tumorigenicity, as there are studies indicating a positive correlation between the expression of several ABC transporters and tumorigenicity (Table 2). However, there are also published studies indicating either no correlation or a negative correlation between the expression of $A B C$ transporters and tumorigenicity (Table 2).

For example, clinical observations and genetic data from mouse models demonstrate that ABCB5 may 
Table 2: Effects of ABC Transporters on Tumorigenicity in Tumor Stem-Like Cells

\begin{tabular}{|c|c|c|c|}
\hline ABC Transporters & Effects on Tumorigenicity & Cancer types & Ref. \\
\hline ABCB1 & Positive & $\begin{array}{l}\text { breast cancer, } \\
\text { uveal melanoma }\end{array}$ & {$[103,104]$} \\
\hline ABCB5 & Positive & $\begin{array}{l}\text { Melanoma, colorectal cancer, oral } \\
\text { squamous cell carcinoma }\end{array}$ & {$[19,105-107]$} \\
\hline ABCB6 & Positive & hepatocellular carcinoma & [108] \\
\hline $\mathrm{ABCC} 4$ & Positive & pancreatic cancer & [109] \\
\hline \multirow{3}{*}{ ABCG2 } & Positive & $\begin{array}{c}\text { Gliomas, gallbladder cancer, ovarian } \\
\text { cancer }\end{array}$ & [110-112] \\
\hline & Negative & nasopharyngeal carcinoma & [113] \\
\hline & NE & $\begin{array}{c}\text { cell lines (U373 glioma and MCF7 } \\
\text { breast cancer) and a xenograft prostate } \\
\text { tumor (LAPC-9) }\end{array}$ & [114] \\
\hline
\end{tabular}

Note: ABC, ATP-binding cassette; Positive, promoting tumorigenicity; Negative, inhibiting tumorigenicity; NE, no effect on tumorigenicity.

contribute to the high tumorigenic capacity of several kinds of human cancer stem-like cells [19, 105-107]. In serial human-to-mouse xenotransplantation experiments by Tobias Schatton et al. [19], ABCB5+ melanoma cells were shown to have a greater tumorigenic capacity than ABCB5- bulk populations. Martin Grimm et al. reported that ABCB5 expression in oral squamous cell carcinoma cells may be associated with tumor formation [106]. Moreover, a ABCB5 ${ }^{+}$ melanoma subpopulation can trigger tumorigenesis through enhanced self-renewal [107]. In addition to ABCB5, there are some studies shows that ABCC4, Pgp and ABCB6 could also promote the process of tumorigenicity of pancreatic cancer cells, breast cancer cells and uveal melanoma cells, respectively [104, 108, 109]. In general, side population cells (mainly mediated by ABCG2) always possess a higher tumorigenic capacity relative to the non-side population cells. However, an in vivo study by Lubna Patrawala et al. found that although side population cells show an increased ABCG2 mRNA expression relative to the non-side population cells, highly purified $\mathrm{ABCG}^{+}$ cancer cells have tumorigenicity similar to the ABCG2 cancer cells [114]. Therefore, the higher tumorigenicity of the side population cells may be resulted from the combined effects of several other subpopulations of cells, in addition to the $\mathrm{ABCG}^{+}$cells. For example, cells expressing other $A B C$ family members, such as MDR1 and MRP1 may also contribute to the cancer cell side population phenotype. However, it has been reported that the cloning efficiency of $A B C G 2^{+}$cells was lower than that of ABCG2 cells and unsorted cells, and the tumorigenic capacity of $\mathrm{ABCG}^{+}$cells was also the lowest. These results may have been due to the presence of other components that enrich side populations and thus there are non-side populations in
$\mathrm{ABCG}^{+}$cells and there are some side populations in ABCG2 ${ }^{-}$cells. In addition, $\mathrm{ABCG}^{+}$cells are not equal to side population cells and therefore do not exhibit typical properties of tumor stem-like cells.

Together, these studies indicate that the expression profile of $A B C$ transporters may play a fundamental role in the process of tumorigenesis. However, to date, most of the evidence is largely correlative and further studies are needed to uncover the definite relationship between $A B C$ transporters and tumorigenesis.

\section{FUTURE DIRECTION}

Currently, the clinically used antineoplastic drugs primarily target rapidly proliferating tumor cells, and have virtually no effect on cancer stem cells, thereby leading to tumor recurrence and metastasis. Therefore, the development of treatment regimens that target cancer stem cells could significantly decrease the likelihood of therapeutic failure and relapse. We have reviewed studies reporting that certain $A B C$ transporters may play a role in maintaining the CSC phenotype. In our opinion, the effective treatment of cancer should involve the treatments that not only reduce the number of proliferating cancer cells but also ones that target CSCs. However, additional research will be required to determine the mechanism(s) by which ABC transporters mediate the self-renewal property of CSCs. We believe that as the mechanism is clarified step by step, the treatment of malignant neoplastic disease will be more effective.

\section{ACKNOWLEDGEMENTS}

This work was supported by major science and technology project of the National Basic Research 
Program (973 Program) of China (No. 2012CB967004) and National Natural Sciences Foundation of China (No. 81072669 and No. 81061160507).

\section{REFERENCES}

[1] O'Shaughnessy JA, et al. Retroviral mediated transfer of the human multidrug resistance gene (MDR-1) into hematopoietic stem cells during autologous transplantation after intensive chemotherapy for metastatic breast cancer. Hum Gene Ther 1994; 5(7): 891-911.

http://dx.doi.org/10.1089/hum.1994.5.7-891

[2] de Figueiredo-Pontes LL, et al. Determination of Pglycoprotein, MDR-related protein 1, breast cancer resistance protein, and lung-resistance protein expression in leukemic stem cells of acute myeloid leukemia. Cytometry B Clin Cytom 2008; 74(3): 163-8.

http://dx.doi.org/10.1002/cyto.b.20403

[3] Albarenque SM, Zwacka RM, Mohr A. Both human and mouse mesenchymal stem cells promote breast cancer metastasis. Stem Cell Res 2011; 7(2): 163-71. http://dx.doi.org/10.1016/..scr.2011.05.002

[4] Seol HJ, et al. Genetically engineered human neural stem cells with rabbit carboxyl esterase can target brain metastasis from breast cancer. Cancer Lett 2011; 311(2): $152-9$.

http://dx.doi.org/10.1016/j.canlet.2011.07.001

[5] Yang L, et al. Gastric cancer stem-like cells possess higher capability of invasion and metastasis in association with a mesenchymal transition phenotype. Cancer Lett 2011; 310(1): 46-52.

[6] Mulholland DJ, et al. Pten loss and RAS/MAPK activation cooperate to promote EMT and metastasis initiated from prostate cancer stem/progenitor cells. Cancer Res 2012; 72(7): 1878-89.

http://dx.doi.org/10.1158/0008-5472.CAN-11-3132

[7] Chiba T, et al. Cancer stem cells in hepatocellular carcinoma: Recent progress and perspective. Cancer Lett 2009; 286(2): 145-53.

http://dx.doi.org/10.1016/j.canlet.2009.04.027

[8] Al-Hajj M, Clarke MF. Self-renewal and solid tumor stem cells. Oncogene 2004; 23(43): 7274-82. http://dx.doi.org/10.1038/sj.onc. 1207947

[9] Schinkel AH, Jonker JW. Mammalian drug efflux transporters of the ATP binding cassette (ABC) family: an overview. Adv Drug Deliv Rev 2003; 55(1): 3-29. http://dx.doi.org/10.1016/S0169-409X(02)00169-2

[10] Gottesman MM, Fojo T, Bates SE. Multidrug resistance in cancer: role of ATP-dependent transporters. Nat Rev Cancer 2002; 2(1): 48-58.

http://dx.doi.org/10.1038/nrc706

[11] Glavinas $\mathrm{H}$, et al. The role of $A B C$ transporters in drug resistance, metabolism and toxicity. Curr Drug Deliv 2004; 1(1): 27-42.

http://dx.doi.org/10.2174/1567201043480036

[12] Vasiliou V, Vasiliou K, Nebert DW. Human ATP-binding cassette (ABC) transporter family. Hum Genomics 2009; 3(3): $281-90$

http://dx.doi.org/10.1186/1479-7364-3-3-281

[13] Dean M, Rzhetsky A, Allikmets R. The human ATP-binding cassette $(A B C)$ transporter superfamily. Genome Res 2001; 11(7): 1156-66.

http://dx.doi.org/10.1101/gr.GR-1649R

[14] Yu M, Ocana A, Tannock IF. Reversal of ATP-binding cassette drug transporter activity to modulate chemoresistance: why has it failed to provide clinical benefit? Cancer Metastasis Rev 2013; 32(1-2): 211-27.

http://dx.doi.org/10.1007/s10555-012-9402-8
[15]

Sharom FJ. ABC multidrug transporters: structure, function and role in chemoresistance. Pharmacogenomics 2008; 9(1): 105-27.

http://dx.doi.org/10.2217/14622416.9.1.105

[16] Hardwick LJ, Velamakanni S, van Veen HW. The emerging pharmacotherapeutic significance of the breast cancer resistance protein (ABCG2). Br J Pharmacol 2007; 151(2): 163-74.

http://dx.doi.org/10.1038/sj.bjp.0707218

[17] Calcagno $A M$, et al. ABC drug transporters as molecular targets for the prevention of multidrug resistance and drugdrug interactions. Curr Drug Deliv 2007; 4(4): 324-33. http://dx.doi.org/10.2174/156720107782151241

[18] Frank NY, Frank MH. ABCB5 gene amplification in human leukemia cells. Leuk Res 2009; 33(10): 1303-5. http://dx.doi.org/10.1016/i.leukres.2009.04.035

[19] Schatton $T$, et al. Identification of cells initiating human melanomas. Nature 2008; 451(7176): 345-9. http://dx.doi.org/10.1038/nature06489

[20] Donnenberg VS, Donnenberg AD. Multiple drug resistance in cancer revisited: the cancer stem cell hypothesis. J Clin Pharmacol 2005; 45(8): 872-7.

http://dx.doi.org/10.1177/0091270005276905

[21] Longley DB, Johnston PG. Molecular mechanisms of drug resistance. J Pathol 2005; 205(2): 275-92. http://dx.doi.org/10.1002/path.1706

[22] Andreeff M, Konopleva M. Mechanisms of drug resistance in AML. Cancer Treat Res 2002; 112: 237-62. http://dx.doi.org/10.1007/978-1-4615-1173-1_12

[23] Gottesman MM, Pastan I. Biochemistry of multidrug resistance mediated by the multidrug transporter. Annu Rev Biochem 1993; 62: 385-427.

http://dx.doi.org/10.1146/annurev.bi.62.070193.002125

[24] Fletcher JI, et al. ABC transporters in cancer: more than just drug efflux pumps. Nat Rev Cancer 2010; 10(2): 147-56.

http://dx.doi.org/10.1038/nrc2789

[25] Ambudkar SV, et al. Biochemical, cellular, and pharmacological aspects of the multidrug transporter. Annu Rev Pharmacol Toxicol 1999; 39: 361-98. http://dx.doi.org/10.1146/annurev.pharmtox.39.1.361

[26] Gerlach JH, et al. P-glycoprotein in human sarcoma: evidence for multidrug resistance. J Clin Oncol 1987; 5(9): 1452-60.

[27] Kuwazuru $\mathrm{Y}$, et al. Expression of the multidrug transporter, $\mathrm{P}$ glycoprotein, in acute leukemia cells and correlation to clinical drug resistance. Cancer 1990; 66(5): 868-73. http://dx.doi.org/10.1002/10970142(19900901)66:5<868::AID CNCR2820660510>3.0.CO:2-Z

[28] Clarke MF, et al. Cancer stem cells--perspectives on current status and future directions: AACR Workshop on cancer stem cells. Cancer Res 2006; 66(19): 9339-44.

\section{http://dx.doi.org/10.1158/0008-5472.CAN-06-3126}

[29] Szotek PP, et al. Ovarian cancer side population defines cells with stem cell-like characteristics and Mullerian Inhibiting Substance responsiveness. Proc Natl Acad Sci USA 2006; 103(30): 11154-9.

\section{http://dx.doi.org/10.1073/pnas.0603672103}

[30] Hirschmann-Jax C, et al. A distinct "side population" of cells with high drug efflux capacity in human tumor cells. Proc Natl Acad Sci USA 2004; 101(39): 14228-33. http://dx.doi.org/10.1073/pnas.0400067101

[31] Ho MM, et al. Side population in human lung cancer cell lines and tumors is enriched with stem-like cancer cells. Cancer Res 2007; 67(10): 4827-33.

http://dx.doi.org/10.1158/0008-5472.CAN-06-3557 
[32] Wang $\mathrm{J}$, et al. Identification of cancer stem cell-like side population cells in human nasopharyngeal carcinoma cell line. Cancer Res 2007; 67(8): 3716-24 http://dx.doi.org/10.1158/0008-5472.CAN-06-4343

[33] Costello RT, et al. Human acute myeloid leukemia CD34+/CD38- progenitor cells have decreased sensitivity to chemotherapy and Fas-induced apoptosis, reduced immunogenicity, and impaired dendritic cell transformation capacities. Cancer Res 2000; 60(16): 4403-11.

[34] Jiang $X$, et al. Chronic myeloid leukemia stem cells possess multiple unique features of resistance to BCR-ABL targeted therapies. Leukemia 2007; 21(5): 926-35.

[35] Haraguchi N, et al. Characterization of a side population of cancer cells from human gastrointestinal system. Stem Cells 2006; 24(3): 506-13. http://dx.doi.org/10.1634/stemcells.2005-0282

[36] Raaijmakers $\mathrm{MH}$, et al. Breast cancer resistance protein in drug resistance of primitive CD34+38- cells in acute myeloid leukemia. Clin Cancer Res 2005; 11(6): 2436-44. http://dx.doi.org/10.1158/1078-0432.CCR-04-0212

[37] Dean M, Fojo T, Bates S. Tumour stem cells and drug resistance. Nat Rev Cancer 2005; 5(4): 275-84. http://dx.doi.org/10.1038/nrc1590

[38] Zhou WJ, et al. Crizotinib (PF-02341066) reverses multidrug resistance in cancer cells by inhibiting the function of $\mathrm{P}$ glycoprotein. Br J Pharmacol 2012; 166(5): 1669-83. http://dx.doi.org/10.1111//.1476-5381.2012.01849.x

[39] Jovelet $\mathrm{C}$, et al. Inhibition of P-glycoprotein functionality by vandetanib may reverse cancer cell resistance to doxorubicin. Eur J Pharm Sci 2012; 46(5): 484-91. http://dx.doi.org/10.1016/j.ejps.2012.03.012

[40] Shen $\mathrm{Y}$, et al. Mitochondrial localization of P-glycoprotein in the human breast cancer cell line MCF-7/ADM and its functional characterization. Oncol Rep 2012; 27(5): 1535-40.

[41] Gibalova L, et al. P-glycoprotein depresses cisplatin sensitivity in L1210 cells by inhibiting cisplatin-induced caspase-3 activation. Toxicol In Vitro 2012; 26(3): 435-44. http://dx.doi.org/10.1016/j.tiv.2012.01.014

[42] Sulova $Z$, et al. Does any relationship exist between Pglycoprotein-mediated multidrug resistance and intracellular calcium homeostasis. Gen Physiol Biophys 2009; 28 Spec No Focus: F89-95.

[43] Barancik M, et al. Reversal effects of several Ca(2+)-entry blockers, neuroleptics and local anaesthetics on Pglycoprotein-mediated vincristine resistance of L1210/VCR mouse leukaemic cell line. Drugs Exp Clin Res 1994; 20(1): 13-8.

[44] Witkowski JM, Miller RA. Calcium signal abnormalities in murine $\mathrm{T}$ lymphocytes that express the multidrug transporter P-glycoprotein. Mech Ageing Dev 1999; 107(2): 165-80. http://dx.doi.org/10.1016/S0047-6374(98)00147-X

[45] Gutheil JC, et al. Alterations in Ca2+ transport ATPase and P-glycoprotein expression can mediate resistance to thapsigargin. J Biol Chem 1994; 269(11): 7976-81.

[46] Wagner-Souza K, et al. Resistance to thapsigargin-induced intracellular calcium mobilization in a multidrug resistant tumour cell line. Mol Cell Biochem 2003; 252(1-2): 109-16. http://dx.doi.org/10.1023/A:1025586225941

[47] Munoz $M$, et al. Role of the MRP1/ABCC1 multidrug transporter protein in cancer. IUBMB Life 2007; 59(12): 7527.

http://dx.doi.org/10.1080/15216540701736285

[48] Cole SP, et al. Overexpression of a transporter gene in a multidrug-resistant human lung cancer cell line. Science 1992; 258(5088): 1650-4

http://dx.doi.org/10.1126/science.1360704
[49] Deeley RG, Cole SP. Substrate recognition and transport by multidrug resistance protein 1 (ABCC1). FEBS Lett 2006; 580(4): 1103-11. http://dx.doi.org/10.1016/j.febslet.2005.12.036

[50] Marques DS, et al. Relationships between multidrug resistance (MDR) and stem cell markers in human chronic myeloid leukemia cell lines. Leuk Res 2010; 34(6): 757-62. http://dx.doi.org/10.1016/j.leukres.2009.11.004

[51] Vesuna F, et al. Twist modulates breast cancer stem cells by transcriptional regulation of CD24 expression. Neoplasia 2009; 11(12): 1318-28.

[52] Pajic M, et al. The role of the multidrug resistance-associated protein 1 gene in neuroblastoma biology and clinical outcome. Cancer Lett 2005; 228(1-2): 241-6. http://dx.doi.org/10.1016/j.canlet.2005.01.060

[53] Haber M, et al. Altered expression of the MYCN oncogene modulates MRP gene expression and response to cytotoxic drugs in neuroblastoma cells. Oncogene 1999; 18(17): 2777 82.

\section{http://dx.doi.org/10.1038/sj.onc. 1202859}

[54] Kuss BJ, et al. In vitro and in vivo downregulation of MRP1 by antisense oligonucleotides: a potential role in neuroblastoma therapy. Int J Cancer 2002; 98(1): 128-33. http://dx.doi.org/10.1002/ijc.10159

[55] Doyle LA, et al. A multidrug resistance transporter from human MCF-7 breast cancer cells. Proc Natl Acad Sci USA 1998; 95(26): 15665-70 http://dx.doi.org/10.1073/pnas.95.26.15665

[56] Zhou S, et al. Bcrp1 gene expression is required for norma numbers of side population stem cells in mice, and confers relative protection to mitoxantrone in hematopoietic cells in vivo. Proc Natl Acad Sci USA 2002; 99(19): 12339-44. http://dx.doi.org/10.1073/pnas.192276999

[57] Doyle L, Ross DD. Multidrug resistance mediated by the breast cancer resistance protein BCRP (ABCG2). Oncogene 2003; 22(47): 7340-58.

http://dx.doi.org/10.1038/sj.onc. 1206938

[58] Bhatia $P$, et al. Breast cancer resistance protein (BCRP/ABCG2) localises to the nucleus in glioblastoma multiforme cells. Xenobiotica 2012; 42(8): 748-55. http://dx.doi.org/10.3109/00498254.2012.662726

[59] Lou H, Dean M. Targeted therapy for cancer stem cells: the patched pathway and ABC transporters. Oncogene 2007; 26(9): 1357-60 http://dx.doi.org/10.1038/sj.onc. 1210200

[60] Sulova Z, et al. The presence of P-glycoprotein in L1210 cells directly induces down-regulation of cell surface saccharide targets of concanavalin A. Anticancer Res 30(9): 3661-8.

[61] Luquain-Costaz C, et al. Bis(monoacylglycero)phosphate accumulation in macrophages induces intracellular cholesterol redistribution, attenuates liver-X receptor/ATPBinding cassette transporter A1/ATP-binding cassette transporter G1 pathway, and impairs cholesterol efflux. Arterioscler Thromb Vasc Biol 33(8): 1803-11.

[62] Molofsky AV, Pardal R, Morrison SJ. Diverse mechanisms regulate stem cell self-renewal. Curr Opin Cell Biol 2004; 16(6): 700-7.

http://dx.doi.org/10.1016/j.ceb.2004.09.004

[63] Oesterle EC, et al. Sox2 and JAGGED1 expression in norma and drug-damaged adult mouse inner ear. J Assoc Res Otolaryngol 2008; 9(1): 65-89. http://dx.doi.org/10.1007/s10162-007-0106-7

[64] Episkopou V. SOX2 functions in adult neural stem cells. Trends Neurosci 2005; 28(5): 219-21. http://dx.doi.org/10.1016/j.tins.2005.03.003

[65] Dong Z, et al. Increased expression of OCT4 is associated with low differentiation and tumor recurrence in human 
hepatocellular carcinoma. Pathol Res Pract 2012; 208(9): 527-33.

http://dx.doi.org/10.1016/j.prp.2012.05.019

[66] Tsai CC, et al. Oct4 and Nanog directly regulate Dnmt1 to maintain self-renewal and undifferentiated state in mesenchymal stem cells. Mol Cell 2012; 47(2): 169-82. http://dx.doi.org/10.1016/j.molcel.2012.06.020

[67] Oka M, et al. Differential role for transcription factor Oct4 nucleocytoplasmic dynamics in somatic cell reprogramming and self-renewal of embryonic stem cells. J Biol Chem 2013; 288(21): 15085-97.

http://dx.doi.org/10.1074/jbc.M112.448837

[68] Tsai CC, et al. Oct4 and Nanog directly regulate Dnmt1 to maintain self-renewal and undifferentiated state in mesenchymal stem cells. Mol Cell 47(2): 169-82.

[69] da Cunha JM, et al. Pluripotent stem cell transcription factors during human odontogenesis. Cell Tissue Res 353(3): 43541.

[70] da Cunha JM, et al. Pluripotent stem cell transcription factors during human odontogenesis. Cell Tissue Res 2013; 353(3): 435-41.

http://dx.doi.org/10.1007/s00441-013-1658-y

[71] Varlakhanova NV, et al. myc maintains embryonic stem cell pluripotency and self-renewal. Differentiation 2010; 80(1): 919.

http://dx.doi.org/10.1016/j.diff.2010.05.001

[72] Wang $\mathrm{Y}$, et al. Bmi-1 regulates self-renewal, proliferation and senescence of human fetal neural stem cells in vitro. Neurosci Lett 2010; 476(2): 74-8. http://dx.doi.org/10.1016/j.neulet.2010.04.006

[73] Lukacs $\mathrm{RU}$, et al. Bmi-1 is a crucial regulator of prostate stem cell self-renewal and malignant transformation. Cell Stem Cell 2010; 7(6): 682-93. http://dx.doi.org/10.1016/j.stem.2010.11.013

[74] Raaphorst FM, Self-renewal of hematopoietic and leukemic stem cells: a central role for the Polycomb-group gene Bmi-1. Trends Immunol 2003; 24(10): 522-4.

\section{http://dx.doi.org/10.1016/S1471-4906(03)00241-2}

[75] Iwama A, et al. Enhanced self-renewal of hematopoietic stem cells mediated by the polycomb gene product Bmi-1. Immunity 2004; 21(6): 843-51. http://dx.doi.org/10.1016/.immuni.2004.11.004

[76] Iwama A, et al. Epigenetic regulation of hematopoietic stem cell self-renewal by polycomb group genes. Int $\mathrm{J}$ Hematol 2005; 81(4): 294-300. http://dx.doi.org/10.1532/IJH97.05011

[77] Nakauchi $\mathrm{H}$, et al. Polycomb gene product $\mathrm{Bmi}-1$ regulates stem cell self-renewal. Ernst Schering Res Found Workshop 2005; (54): 85-100.

[78] Gong H, Zhang YC, Liu WL. [Regulatory effects of Bmi-1 gene on self-renewal of hematopoietic stem cells--review]. Zhongguo Shi Yan Xue Ye Xue Za Zhi 2006; 14(2): 413-5.

[79] Oguro H. [Regulation of hematopoietic stem cell self-renewal by a polycomb group gene product, Bmi-1]. Rinsho Ketsueki 2006; 47(5): 363-70.

[80] Balenci L, van der Kooy D. Notch signaling induces retinal stem-like properties in perinatal neural retina progenitors and promotes symmetric divisions in adult retinal stem cells. Stem Cells Dev 2013;

[81] Zheng $\mathrm{Y}$, et al. A rare population of CD24(+)ITGB4(+) Notch(hi) cells drives tumor propagation in NSCLC and requires Notch3 for self-renewal. Cancer Cell 2013; 24(1): 59-74. http://dx.doi.org/10.1016/j.ccr.2013.05.021

[82] Heidel FH, Mar BG, Armstrong SA. Self-renewal related signaling in myeloid leukemia stem cells. Int J Hematol 2011; 94(2): 109-17.

http://dx.doi.org/10.1007/s12185-011-0901-0
[83] Cai C, Zhu X. The Wnt/beta-catenin pathway regulates selfrenewal of cancer stem-like cells in human gastric cancer. Mol Med Rep 2012; 5(5): 1191-6.

[84] Huang $\mathrm{J}$, et al. Maintenance of hematopoietic stem cells through regulation of Wnt and mTOR pathways. Nat Med 2012; 18(12): 1778-85.

http://dx.doi.org/10.1038/nm.2984

[85] Merrill BJ. Wnt pathway regulation of embryonic stem cell self-renewal. Cold Spring Harb Perspect Biol 2012; 4(9): a007971;

[86] Park JS, et al. Six2 and Wnt regulate self-renewal and commitment of nephron progenitors through shared gene regulatory networks. Dev Cell 2012; 23(3): 637-51. http://dx.doi.org/10.1016/j.devcel.2012.07.008

[87] Nusslein-Volhard C, Wieschaus E. Mutations affecting segment number and polarity in Drosophila. Nature 1980; 287(5785): 795-801.

http://dx.doi.org/10.1038/287795a0

[88] Ingham PW, McMahon AP. Hedgehog signaling in animal development: paradigms and principles. Genes Dev 2001; 15(23): 3059-87. http://dx.doi.org/10.1101/gad.938601

[89] Keshet GI, et al. MDR1 expression identifies human melanoma stem cells. Biochem Biophys Res Commun 2008; 368(4): 930-6.

http://dx.doi.org/10.1016/j.bbrc.2008.02.022

[90] Sims-Mourtada J, et al. Sonic Hedgehog promotes multiple drug resistance by regulation of drug transport. Oncogene 2007; 26(38): 5674-9. http://dx.doi.org/10.1038/sj.onc. 1210356

[91] Sims-Mourtada J, et al. Hedgehog: an attribute to tumor regrowth after chemoradiotherapy and a target to improve radiation response. Clin Cancer Res 2006; 12(21): 6565-72. http://dx.doi.org/10.1158/1078-0432.CCR-06-0176

[92] Santisteban M. ABC transporters as molecular effectors of pancreatic oncogenic pathways: the Hedgehog-GLI model. J Gastrointest Cancer 2010; 41(3): 153-8.

http://dx.doi.org/10.1007/s12029-010-9144-1

[93] Zeng $\mathrm{H}$, et al. Lack of ABCG2 expression and side population properties in human pluripotent stem cells. Stem Cells 2009; 27(10): 2435-45. http://dx.doi.org/10.1002/stem.192

[94] Susanto J, et al. Porphyrin homeostasis maintained by ABCG2 regulates self-renewal of embryonic stem cells. PLoS One 2008; 3(12): e4023;

[95] Lobo NA, et al. The biology of cancer stem cells. Annu Rev Cell Dev Biol 2007; 23: 675-99.

http://dx.doi.org/10.1146/annurev.cellbio.22.010305.104154

[96] Loh $\mathrm{YH}$, et al. The Oct4 and Nanog transcription network regulates pluripotency in mouse embryonic stem cells. Nat Genet 2006; 38(4): 431-40 http://dx.doi.org/10.1038/ng1760

[97] Masui S, et al. Pluripotency governed by Sox2 via regulation of Oct3/4 expression in mouse embryonic stem cells. Nat Cell Biol 2007; 9(6): 625-35. http://dx.doi.org/10.1038/ncb1589

[98] Zabierowski SE, Herlyn M. Learning the ABCs of melanomainitiating cells. Cancer Cell 2008; 13(3): 185-7. http://dx.doi.org/10.1016/j.ccr.2008.02.015

[99] Juuti-Uusitalo $\mathrm{K}$, et al. Efflux protein expression in human stem cell-derived retinal pigment epithelial cells. PLoS One 2012; 7(1): e30089;

[100] Barbet R, et al. Expression of the 49 human ATP binding cassette $(A B C)$ genes in pluripotent embryonic stem cells and in early- and late-stage multipotent mesenchymal stem cells: possible role of $\mathrm{ABC}$ plasma membrane transporters in maintaining human stem cell pluripotency. Cell Cycle 2012; 11(8): 1611-20

http://dx.doi.org/10.4161/cc.20023 
[101] Islam $\mathrm{MO}$, et al. Characterization of $A B C$ transporter $A B C B 1$ expressed in human neural stem/progenitor cells. FEBS Lett 2005; 579(17): 3473-80. http://dx.doi.org/10.1016/i.febslet.2005.05.019

[102] Cheepala S, et al. Cyclic nucleotide compartmentalization: contributions of phosphodiesterases and ATP-binding cassette transporters. Annu Rev Pharmacol Toxicol 2013; 53: 231-53. http://dx.doi.org/10.1146/annurev-pharmtox-010611-134609

[103] Calcagno AM, et al. Prolonged drug selection of breast cancer cells and enrichment of cancer stem cell characteristics. J Natl Cancer Inst 2010; 102(21): 1637-52. http://dx.doi.org/10.1093/jnci/djq361

[104] Landreville $S$, et al. ABCB1 identifies a subpopulation of uveal melanoma cells with high metastatic propensity. Pigment Cell Melanoma Res 2011; 24(3): 430-7. http://dx.doi.org/10.1111/j.1755-148X.2011.00841.x

[105] Wilson BJ, et al. ABCB5 identifies a therapy-refractory tumor cell population in colorectal cancer patients. Cancer Res 2011; 71(15): 5307-16. http://dx.doi.org/10.1158/0008-5472.CAN-11-0221

[106] Grimm M, et al. ABCB5 expression and cancer stem cell hypothesis in oral squamous cell carcinoma. Eur $\mathrm{J}$ Cancer 2012; 48(17): 3186-97. http://dx.doi.org/10.1016/j.ejca.2012.05.027

[107] Lin JY, et al. Genetically determined ABCB5 functionality correlates with pigmentation phenotype and melanoma risk. Biochem Biophys Res Commun 2013; 436(3): 536-42. http://dx.doi.org/10.1016/.j.bbrc.2013.06.006
[108] Polireddy K, et al. Functional significance of the ATP-binding cassette transporter B6 in hepatocellular carcinoma. Mol Oncol 2011; 5(5): 410-25 http://dx.doi.org/10.1016/j.molonc.2011.07.005

[109] Zhang Z, et al. The ABCC4 gene is a promising target for pancreatic cancer therapy. Gene 2012; 491(2): 194-9. http://dx.doi.org/10.1016/j.gene.2011.09.029

[110] Bleau AM, et al. PTEN/PI3K/Akt pathway regulates the side population phenotype and ABCG2 activity in glioma tumor stem-like cells. Cell Stem Cell 2009; 4(3): 226-35. http://dx.doi.org/10.1016/i.stem.2009.01.007

[111] Li XX, et al. Characterization of cancer stem-like cells derived from a side population of a human gallbladder carcinoma cell line, SGC-996. Biochem Biophys Res Commun 419(4): 72834.

[112] Luo LJ, et al. [Analysis of the characteristics of side population cells in the human ovarian cancer cell line OVCAR-3]. Zhonghua Fu Chan Ke Za Zhi 47(4): 281-5.

[113] Zhang $\mathrm{H}$, et al. Identification of ABCG2(+) cells in nasopharyngeal carcinoma cells. Oncol Rep 27(4): 1177-87.

[114] Patrawala $L$, et al. Side population is enriched in tumorigenic, stem-like cancer cells, whereas ABCG2+ and ABCG2cancer cells are similarly tumorigenic. Cancer Res 2005; 65(14): 6207-19. http://dx.doi.org/10.1158/0008-5472.CAN-05-0592 